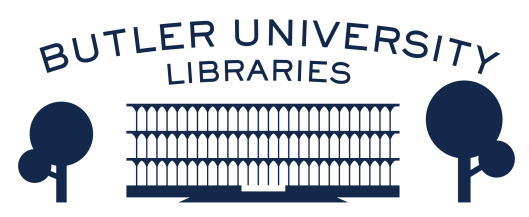

Journal of Hindu-Christian Studies

Volume 26

Article 8

November 2013

\title{
Christians and Vedic Sacrifice: Comparing Communitarian Sacrificial Soteriologies
}

Christopher Denny

St. John's University (NY)

Follow this and additional works at: https://digitalcommons.butler.edu/jhcs

Part of the Religion Commons

\section{Recommended Citation}

Denny, Christopher (2013) "Christians and Vedic Sacrifice: Comparing Communitarian Sacrificial Soteriologies," Journal of Hindu-Christian Studies: Vol. 26, Article 8.

Available at: https://doi.org/10.7825/2164-6279.1547

The Journal of Hindu-Christian Studies is a publication of the Society for Hindu-Christian Studies. The digital version is made available by Digital Commons @ Butler University. For questions about the Journal or the Society, please contact cbauman@butler.edu. For more information about Digital Commons @ Butler University, please contact digitalscholarship@butler.edu. 


\title{
Christians and Vedic Sacrifice: Comparing Communitarian Sacrificial Soteriologies
}

\author{
Christopher Denny \\ St. John's University (NY)
}

CAN there be a constructive Christian appropriation of understandings of religious sacrifice from another religious tradition? As far back as the first-century letter to the Hebrews, Christians defined the efficacy of Jesus Christ's sacrifice over and against previous sacrifices in the Temple in Jerusalem, and in subsequent centuries have argued that Christ's sacrifice is an unrepeatable historical act manifesting God's favor to human beings. Unless Christian theologians are willing to take the path of liberal pluralism and concede that the sacrifice offered through Jesus of Nazareth is one species within a genus of soteriological possibilities, an epiphenomenon of an underlying reconciliation equally present in various religious traditions, one is hard pressed to understand how the Christian doctrine of atonement represents anything but an impasse in interreligious dialogue.

In an attempt to cross this theological barrier, I turn to some key sacrificial themes in classic Hindu texts for help in resolving contemporary issues facing Christian doctrines of atonement. Recent Christian systematic theology features dissension over the appropriate use of substitutionary, penal, and sacrificial metaphors to describe Jesus' violent death on the cross. Some have urged Christians to abandon penal substitutionary theories of atonement because they distort God into a wrathful patriarch who must be appeased by the violent death of his masochistic Son. ${ }^{1}$ The influential René Girard goes further and argues that the biblical gospels, when properly interpreted, oppose the category of sacrifice itself, which Girard equates with ritual murder. ${ }^{2}$

What if we envision Christian sacrifice as constructive of a community rather than as destructive to participants? What if theologians, taking a cue from generations of social scientists, defined sacrifice primarily in terms of its social effects rather than in terms of an essentialist paradigm by which humans become reconciled to God? Would this

Christopher D. Denny is an associate professor in the Department of Theology and Religious Studies at St. John's University in Queens, New York, teaching courses in patristic and medieval Christian theology. He is the coeditor, with Jeremy Bonner and Mary Beth Fraser Connolly, of Empowering the People of God: Catholic Action before and after Vatican II (Fordham UP, 2013), and with Christopher McMahon, of Finding Salvation in Christ: Essays on Christology and Soteriology in Honor of William P. Loewe (Pickwick, 2011). Other publications include articles in Communio, the Journal of Ecumenical Studies, Logos, Christianity and Literature, and Horizons. He is the recipient of best-article awards from the Catholic Press Association and the College Theology Society. His current research projects articulate ways imaginative literature and non-Christian scriptures can shape Christian anthropology. 
ameliorate some of the problems the critics of substitutionary atonement rightfully identify? Here vedic yajña provides an alternative sacrificial paradigm that overcomes many of these roadblocks, and provides a resource for reemphasizing marginalized sacrificial themes within Christian traditions. The Pūrva Mìmāmsā tradition promotes the doctrine of svatah prāmanyā, "intrinsic validity," and so the Mīmāmsā school of interpretation understands yajña not as a utilitarian exercise in gaining extrinsic goods but rather as a nexus of performances whose value is intrinsic within the sacrificial actions themselves. ${ }^{3}$ This essay is a contribution towards a Christian sacrificial soteriology of svatah prāmanyā, which seeks to reinterpret religious atonement in a communitarian direction without abandoning the category of sacrifice. Within this framework, the representation of the sacrifice in the celebration of the Eucharist or the Lord's Supper need not be distorted into a quasimythological appeasement of an angry deity, or as a literalized metaphor in which one pays off spiritual debt. Instead, the anamnesis and distribution of the material elements in the eucharistic ritual brings about community and salvation that is experienced within the performance itself. ${ }^{4}$

\section{Questioning Assumptions about Individual Agency and Violence in Sacrifice}

One key presumption that I make is that sacrifice is more than simply the stylized public death of a passive individual at one particular point in time. To frame the doctrine of atonement, as one such writer does, with leading questions such as "Who or what needs the death of Jesus? . . . Who ultimately killed Jesus?" highlights the injustice of the crucifixion but also truncates our field of attention towards one man who died on Calvary rather than the many who lived through that day. ${ }^{5}$ The individualized focus is present when the same writer states:

A victim is controlled by forces and circumstances beyond himself or herself. A victim surrenders control to others and accepts the injustice imposed by others. Jesus in satisfaction and substitutionary atonement models victimization. When this atonement motif is the model for people who have experienced abuse or exploitation, this model underscores their status as victims. ${ }^{6}$

Questions of agency, activity, and passivity loom large in this line of recent soteriological argument, but unduly obscure the communitarian focus these authors promote, for concerns about individual agency in atonement theology already privilege modern liberalism's assumption that the exercise of free agency is what saves people. Perhaps this assumption could be demonstrated to be true, but without such a demonstration the effects of salvific agency gravitate to a libertarian frame of reference in which agency equals salvation tout court. ${ }^{7}$

Kathryn McClymond, in her recent book Beyond Sacred Violence: A Comparative Study of Sacrifice, has demonstrated that modern Western articulations and denunciations of religious sacrifice across various religious traditions are reductive and unreflectively shaped by Jesus' crucifixion. For example, McClymond traces how Henri Hubert, Marcel Mauss, and others center sacrifice upon killing, even for the vegetal offerings that in many societies constitute the majority of sacrificial 
practices. Even in animal sacrifices killing is only one part of the ritual, and responsible comparative theology should be ready to examine other ritual constructions that operate from different presumptions. Moreover, if comparative theology pays due heed to ritual performance it should follow Mcclymond's recommendation that a polythetic understanding of sacrifice "draws attention to the importance of the interactions between activities" rather than isolating one performative element to provide Christianinfluenced grist for a creedal mill. ${ }^{8}$ As interpreted by the Mīmāṃsakas, Vedic yajña provides one alternative ritual construction.

\section{Vedic Sacrifice as a Communitarian Soteriology}

Spatial constraints forbid an expansive presentation of the vedic texts that provide the foundation for the soteriological contrast I am drawing here. I begin with Brian Smith's observation. In Reflections on Resemblance, Ritual and Religion he wrote: "The sacrifice was displayed as a constructive activity, creating the human being, the afterlife, and the cosmos as a whole. It was also, of course, a social instrument-constructing individuals as part of a class and defining both the classified individual and the classes themselves from within the universe of the ritual." ${ }^{9}$ To understand how this process works, we can begin with a representative text from the Śatapatha Brāhmaña about the vegetal soma sacrifice: "Now, in performing that sacrifice, they slay it; and in pressing out the king (Soma), they slay him; and in quieting and immolating the victim, they slay it. The haviryagña they slay with the mortar and pestle, and with the two mill-stones." ${ }^{10}$ The language of killing here is the same as scholars would find used in vedic texts describing animal sacrifice, and the language of quieting or strangling the victim recalls the aśvamedha or horse sacrifice, only here no blood is shed and the ritual does not readily lend itself to a violent interpretation. ${ }^{11}$

When we move to texts dealing with animal sacrifice, the moment of death is often overshadowed by euphemism and concerns about distribution. First, I will deal with euphemism with reference to the horse sacrifice that is the pinnacle of vedic ritual. Consider this excerpt from the Śatapatha Brāhmaña:

They then step back (to the altar) and sit down turning towards the Âhavanîya [fire], 'lest they should be eye-witnesses to its being quieted [strangled].' . . . They either choke it by merely keeping its mouth closed, or they make a noose. Therefore he says not, 'Slay! kill!' for that is [the] human manner, but, 'Quiet it! It has passed away!' for that is after the manner of the gods. ${ }^{12}$

In the Girardian theory of sacrifice as violence, the community internalizes its feelings of guilt after the ritual scapegoating has taken place, honoring and often deifying the now immolated victim. The Śatapatha Brāhmana, however, is more a prescriptive text than a descriptive one. Why would euphemistic language be used for what the Vedic community that produced this Brahmana apparently continued to do on a periodic basis under royal auspices? Nothing in the scapegoat theory seems to hold out the possibility that ritual scapegoating can survive in the age of a second naiveté, for scapegoaters remain ignorant of what they do, which is why increased awareness of the scapegoating 
mechanism in modern times has driven scapegoating into retreat according to Girard. ${ }^{13}$ Moreover, the first excerpt above explicitly distinguishes between slaughter and "quieting," placing an added burden of proof on those who would hold to the position that the surface meaning of the text conceals a collective unawareness of the violence that is at the core of the ritual.

Moving from issues of euphemism to apportionment in vedic animal sacrifice, concerns over distribution of a sacrificial victim also create serious problems for reductionistic equations of sacrifice with violence, for it is very difficult to understand why an animal used as a scapegoat in toto would acquire such value immediately afterwards when consumed piecemeal. The Kätyāyana Śrauta Sūtra provides many examples of detailed instructions for the distribution of animal flesh and organs. Different orders of priests are the designated recipients of particular body parts while other parts are reserved for the deities, with cosmic orientation a key factor. Any interpretation of the process of apportionment that would attempt to marginalize the centrality of this aspect of vedic ritual faces challenges from a passage like this one in the Rig Veda.

Whatever of the horse's flesh the fly has eaten, or whatever stays stuck to the stake or the axe, or to the hands or nails of the slaughterer-let all of that stay with you even among the gods....

Whatever runs of your body when it has been placed on the spit and roasted by the fire, let it not lie there in the earth or on the grass, but let it be given to the gods who long for it. ${ }^{14}$
Here distribution becomes a matter of prayer, with the hope that the sacrificed victim is reconstituted among the gods. Based upon the available body of vedic texts and commentaries, Mcclymond's claim that "the division or apportionment of the offering is more significant than its death" is sound. ${ }^{15}$ McClymond also writes: "Instead of seeing killing as an independent and definitive feature of sacrifice, we need to approach killing as only one of many important-and interdependentelements in a complex ritual." ${ }^{\text {16 }}$

There are significant moral objections that can be made to this hermeneutic practice to which I will respond shortly, but for now I will outline some soteriological consequences that arise in light of these vedic practices. What distinguishes the theology of vedic ritual from that of other civilizations is that in the Vedas sacrifice is held to be constitutive of rta, the cosmic order. Brian Smith puts it succinctly, writing: "In Vedism, ritual activity at all levels does not merely 'interpret,' 'symbolize,' or 'dramatize'; it constitutes, constructs and integrates. Ritual forms the naturally formless; it connects the inherently disconnected; and it heals the 'sickness' of excess which is the state toward which all things and beings perpetually tend." ${ }^{17}$ Sacrificial efficacy is given a transcendental anchor in one of the most famous hymns in the Rig Veda, the PurushaSukta. Here is a creation myth that describes the sacrifice of the cosmic giant, the god Purusha. The gods sacrifice Purusha, and from this sacrifice the whole cosmos is created-the vedic gods Indra and Agni, the animal world, human beings, the sky, the sun and moon, the wind, and language:

Using the Man as their oblation, the Gods performed their sacrifice. 
Spring served them for the clarified butter, Summer for the fuel, and Autumn for the offering.

His mouth became the Brahmin; his arms became the warrior prince, his legs the common man who plies his trade. The lowly serf was born from his feet.

The Moon was born from his mind; the Sun came into being from his eye;

from his mouth came Indra and Agni, while from his breath the Wind was born. ${ }^{18}$

The Purusha-Sukta is not the only creation myth to describe the universe as the product of sacrificial distribution; the Babylonian Enuma Elish describes how the universe and the human race are constructed from the bodies of the gods Tiamat and Kingu, but there the apportionment is destructive, the result of warfare and execution, rather than the consequence of a sacrifice that constitutes a community. In the Purusha-Sukta however, both Indra, the supreme deity in the vedic pantheon, and Agni, the deity who conveys sacrifices to the gods, stand in a subordinate relationship to the creative cosmic sacrifice. Indra and Agni are themselves products of the primeval sacrifice; they are subordinate to it. The Purusha-Sukta offers an immanent view of sacrifice that encompasses all of the cosmos. Sacrifice is not a telegram sent from the earthly world to the world above; instead vedic sacrifice contains an intrinsic validity that is intended to construct and constitute the world itself. $^{19}$

How then do the individual brahminical sacrifices, including the aśvamedha, relate to this original, world-creating sacrifice? Bruce Lincoln, in the process of trying to place the
Purusha-Sukta in the context of similar IndoEuropean myths involving the world-creating sacrifice of a person, puts it this way: "The myth tells us of the origin of the world and also of the origin of the most important human institution-sacrifice. In truth, these are not two separate origins but one. The first sacrifice is the origin of the world, and each repeated sacrifice serves to re-create it." ${ }^{20}$ Each sacrifice draws upon the cosmic power of the original sacrifice to achieve its ends. All subsequent brahminical sacrifices were understood as replicating that original act of creation and rescuing people from the asacrificial possibility of non-being.

\section{How Christians Can Learn from Vedic Sacrificial Soteriology}

I do not claim that Christians should reinstitute a sacrificial cult in imitation of vedic practices. Nor should Christians step away from a theistic worldview to adopt an alternative remythicized understanding of the creation as the product of ritual sacrifice. What I do assert is that vedic sacrificial practice and the mythical conviction that the universe is the product of creative sacrifice provide ways of thinking about Christ's atoning sacrifice as something more than only violence against a single individual. Does this hypothesis, however, mean that we should agree that the violence that is ensconced within some sacrificial rituals, and certainly embedded in Christ's execution at Golgotha, is soteriologically justified so long as communal religious ties are reaffirmed and strengthened thereby? Girard's moral claims in particular haunt attempts to reinterpret Christian atonement as a communitarian sacrificial soteriology because they apparently lead to a 
zero-sum choice in which we either have to abandon the category of sacrifice or affirm the injustice surrounding Christ's death. Must we choose between the perspectives of the sacrificers and the victims? Moreover, the sacrificial community constituted and affirmed in vedic ritual is from the standpoint of modern egalitarianism radically deficient, for it is hierarchical and caste-based. Is that the type of community today's Christians hope to achieve by remembering and representing Christ's sacrifice at their eucharistic celebrations?

Yet even justifiable moral concerns about sacrifice can lead to all-too easy privileging of individualist soteriologies. What if the major soteriological concern with sacrifice should be not who is guilty and who is vindicated, or who is the perpetrator and who is the scapegoat, but rather the type of community that both sides desire to see enacted? There are two headings under which I will follow up on this question; the first heading is theological and the second is moral.

First, a theological preference for a communitarian soteriology would mean that New Testament interpretation should not be hasty in dismissing the social, communitarian, and functional benefits of sacrifice out of a primary concern to stress sacrifice's efficacy in restoring human people to a right relationship with God. For an example of how these two soteriological foci, which are of course not incompatible with one another, can be brought into seeming competition, consider one recent interpretation of atonement from Paul's Letter to the Romans. At a point in his book Saved from Sacrifice, S. Mark Heim attempts to provide theological support for Girard's anthropological claims by separating Paul's language about Christ's atonement in Romans
3:21-26 from questions of divine agency. Heim writes:

How are we to take the phrase "as a sacrifice of atonement"? Is this a specification of the heart of God's purpose, or is it a description of a position, a place taken up by Christ in the service of God's purpose to redeem and ransom humanity? I incline to the latter. God enters into the position of the victim of sacrificial atonement (a position already defined by human practice) and occupies it so as to be able to act from that place to reverse sacrifice and redeem us from it. God steps forward in Jesus to be one subject to the human practice of atonement in blood, not because that is God's preferred logic or because this belief is God's aim, but because this is the very site where human bondage and $\sin$ are enacted. ${ }^{21}$

Heim interprets this passage as a move away from transcendent theo-logic towards an immanent theo-drama. This is a sound development if one wants to secure a christocentric understanding of divine activity, but once New Testament soteriological interpretation moves in this direction why can't we proceed further and follow Paul in using this soteriological claim to rehabilitate the category of sacrifice? If sacrifice is not a strategy to appease the abstract workings of divine providence, then it should not be abandoned as a heuristic device as if that were the only interpretation of sacrifice available. Consider the presumed link between sacrifice and killing that McClymond challenges with her focus on vegetal offerings in vedic tradition. If the vedic yajña can be understood as something more than mere killing and violence, why must a nonviolent Christian 
atonement be nonsacrificial? Heim notes that Romans 3 roots God's saving action not in Christ's blood but in faith in Christ, which is true, but Paul does not separate blood and faith here. $^{22}$ Nor does Paul separate Christ's blood from the new covenant in 1 Corinthians 11:25, where Paul references a saying of Jesus that he has received: "This cup is the new covenant in my blood. Do this, as often as you drink of it, in remembrance of me" (NRSV).

Paul's handing down of the early Christian community's remembrance of Jesus' instructions at his final meal with his disciples echo the synoptic sayings found in Matthew 26:26-29, Mark 14:22-25, and Luke 22:14-20. Girard claims that the gospels provide no support for a sacrificial reading of Christ's death, but the exegetical support that he gives for this assertion is thin. In Things Hidden Since the Foundation of the World he makes reference to Jesus' quotation at Matthew 9:13 of Hosea 6:6: "I desire steadfast love and not sacrifice" as though that verse, when joined with Jesus' admonition in the Sermon on the Mount to be reconciled with one's brother before offering sacrifice (Mt. 5:23-24), is sufficient to establish a nonsacrificial interpretation of the Kingdom of God, the basileia theou. ${ }^{23}$ Neither text, however, offers the global denunciation of sacrifice in itself that Girard claims they do. If Jesus attacks sacrifice in itself, he is certainly being elliptic in his pronouncements. In a passage in his more recent book Evolution and Conversion Girard concedes that "we cannot have a perfectly non-sacrificial space" and that the eucharistic celebration is rooted in archaic cannibalism. ${ }^{24}$ This leads us naturally to the role of Jesus' final meal and its relation to sacrifice in the synoptic gospels.
By offering bread and wine as his body and blood in the context of a Passover meal, Jesus is not repudiating Jewish sacrificial practice but reaffirming its communitarian liberating orientation in a transformed context. In Mark 14:24 and Matthew 26:28 Jesus says that the blood he offers in the meal is that of the covenant shed for many. There is no credible way to escape the sacrificial implications of this statement that recalls the Passover lamb of the Exodus and the delivery of the people of Israel from Egypt. Moreover, Jesus' concern with the distribution of the sacrifice, his instructions to the disciples to eat and drink, offer a point of comparison with the vedic sacrifices I referenced above, in which the ordering of the community is reaffirmed through ritual apportionment. Unlike the sacrificial instructions in Exodus 12, however, here the wine offered as blood is consumed rather than sprinkled at the doorways. This change diffuses the distinctive apotropaic function of the original Passover blood and instead incorporates the wine-blood into the meal that binds the participants together as they ingest the blood. What is external to the bodies of the participants becomes internalized without being privatized, for in Luke 22:28-30 Jesus ratifies a political cosmogony among the apostles by assigning them thrones in his basileia immediately after his distribution of bread and wine. While the Rig Veda provides the narrative of the Purusha-Sukta, the synoptic narratives of eucharistic institution exemplify a Basileia-Sukta or an Ecclesia-Sukta, in which a new community is formed through the sacrificial distribution of elements.

The second heading in this communitarian sketch moves from theological concerns to return to the moral concerns over scapegoating 
62 Christopher Denny

referenced above. We must remember that in some instances sacrifice can serve to divide and undermine communities rather than unite them. To defend the possibility of a constructive communitarian theology of sacrifice is not the same thing as offering a global defense of this practice in every case. McClymond cautions: "I am not arguing that sacrifice upholds a specific ethical code of conduct. Rather, I am arguing that the foundational notion that there is a right way (and a wrong way) to handle certain offerings . . . suggests a sense of 'ought' in the community's worldview." ${ }^{25}$ Sacrificial meals can support hierarchical groupings or more egalitarian movements, but sacrifices do not support abstracted societies. Mary Douglas's lapidary statement, "Solidarity is only gesturing when it involves no sacrifice," applies here. ${ }^{26}$ Killing, cutting, and eating are social acts that provide material and embodied cohesion, in contrast with creedal summaries or privatized affirmations of belief that can be more easily shorn of communitarian commitment.

These parallels between vedic sacrificial meals and the eucharistic distribution provide alternatives to equating sacrifice simply with killing, but what about internalized concepts of sacrifice? In the post-Enlightenment era, has an internalized understanding of sacrifice replaced ritual sacrifice so that ritual is obsolete as a valid heuristic framework when addressing questions of salvation and liberation? After all, each religious tradition described here faced historical crises in which their sacrificial practices were called into question; in each tradition there have been many who have decided, for different reasons, to abandon sacrifice as a heuristic category for soteriology. While the sacrificial interpretation of the Eucharist given above may appeal to Roman Catholics, Christians in the Lutheran tradition have generally followed Luther's nonsacrificial interpretation of the eucharistic ritual set forth in The Babylonian Captivity of the Church, in which sacrifice is understood as a misguided human offering that conflicts with needed receptivity to the promise of christ. ${ }^{27}$ In the Hindu tradition, at the beginning of his commentary on the Brahma Sūtra Śamkara writes:

The special question with regard to the enquiry into Brahman is whether it presupposes as its antecedent the understanding of the acts of religious duty (which is acquired by means of the Pûrvâ Mîmâmsâ). To this question we reply in the negative, because for a man who has read the Vedânta-parts of the Veda it is possible to enter on the enquiry into Brahman even before engaging in the enquiry into religious duty. ${ }^{28}$

Śạ̣kara argued against Mīmāṃsa claims for ritual's efficacy, while for his part Luther sought to dismantle the medieval clericalist structure that he believed obscured the gospel and kept laity from the promise of the gospels. For both authors ritual sacrifice stands in opposition to genuine salvation. ${ }^{29}$

Yet just as a sacrificial interpretation of the Last Supper is possible, so too is a sacrificial reading of upanișadic Vedānta texts. The Upaniṣads react against vedic sacrificial practices by internalizing and extending the idea so that those outside the priestly caste can perform sacrifice. In the Brhad-äranyaka Upanișad, the human person is identified with the world-creating Purusha-Sukta, as in this deathbed ritual: "When a man thinks that he is about to depart, he says to his son, 'you are 
Brahman, you are the sacrifice and you are the world.' The son answers, 'I am Brahman, I am the sacrifice, I am the world.' . . . Verily, whatever sacrifices have been made, all those, taken as one are the world." 30 Verses in the Chāndogya Upanișad continue in this vein. ${ }^{31}$ The first-century Christian movement had to make similar adjustments to its sacrificial practices after the destruction of the Jerusalem Temple, as the sacrificial paradigm outlived the Jewish sacrificial cult. Christians now interpreted the historical event of Jesus' death as a transhistorical reality that could be spiritually accessed through the performance of the Eucharist. Despite the very different Christian and Hindu understandings of historical events and their normativity for subsequent religious practices, ritual sacrifice continued to provide soteriological paradigms for adherents in both traditions even in the face of internal critiques such as those of Luther and Śamkara.

Contemporary Christian theologians are fond of stating that "The economic Trinity is the immanent Trinity" in attempts to correlate the Godhead with salvation history. In this vein theologians such as Colin Gunton have argued that Christian theologies of sacrifice acquire their most comprehensive scope when they articulate sacrifice in trinitarian rather than in cultic language, rooting religious sacrifice in Jesus' eternal kenotic love for his Father. At the close of his book The Promise of Trinitarian Theology, Gunton claims that the Trinity provides a very different definition of sacrifice, one much more amenable in the context of a sacrificial meal-the definition of sacrifice as gift. In language recalling the Purusha-Sukta, Gunton writes: "To be is to exist in a dynamic of mutual giving and receiving. That is a 'sacrificial ontology' of God . . . .
Sacrifice is also a way of understanding the end for which the world is made: to echo the mutual giving and receiving of Father, Son, and Spirit with the dynamics of space and time, as a sacrifice of praise." 32

\section{Conclusion}

I have employed texts on vedic sacrifice to support the assertion that, just as Christian theologians in recent decades have equated the economic and immanent Trinities, they must also be willing to claim, "The economic sacrifice is the immanent sacrifice." In other words, rather than primarily concerning themselves with how Jesus' death on the cross affected his Father, and how Christians' merited or unmerited experiences of suffering join individuals to the redeeming work of Christ, Christians should pay more attention to the Eucharist's svatah prāmanyā, heeding the intrinsic validity that this sacrificial practice have in constituting personhood and community in the life of the church.

An altered understanding of religious sacrifice can break past the barrier of individualism. Maintaining sacrifice as a spiritual imperative, rather than jettisoning sacrifice as critics would do, allows people to recognize how this ancient cross-cultural practice reflexively defines human selves within diverse social environments. At the social level, such a world-constituting conception of sacrifice preserves its responsible use as a moral category that rescues communal aspirations from sentimentalized abstractions, but it can also counter the violent language of heteronomic substitutionary sacrifice in militaristic and nationalistic rhetoric, in which the scapegoat 
to be offered up is too often identified as one's opponent rather than oneself.

\section{Notes}

${ }^{1}$ See J. Denny Weaver, The Nonviolent Atonement (Grand Rapids: Eerdmans, 2001); S. Mark Heim, Saved from Sacrifice: A Theology of the Cross (Grand Rapids: Eerdmans, 2006); Rita Nakashima Brock, "And a Little Child Will Lead Us: Christology and Child Abuse"; in Christianity, Patriarchy, and Abuse: A Feminist Critique, eds. Joanne Carlson Brown and Carole R. Bohn (New York: Pilgrim, 1989), $42-61$. http://dx.doi.org/2027/mdp.39015015476719

${ }^{2}$ See René Girard, Violence and the Sacred, trans. Patrick Gregory (Baltimore: Johns Hopkins University Press, 1977); The Scapegoat, trans. Yvonne Freccero (Baltimore: Johns Hopkins University Press, 1986); Things Hidden Since the Foundation of the World, trans. Stephen Bann and Michael Metteer (Stanford: Stanford University Press, 1987).

${ }^{3}$ For a helpful essay on this point linking Pūrva Mīmāmsā to current philosophical debates regarding foundationalism and its opponents, see Daniel Arnold, "Intrinsic Validity: A Study on the Relevance of Pūrva Mìmāmsā," Philosophy East and West 51, no. 1 (Jan. 2001): 26-53.

http://dx.doi.org/10.1353/pew.2001.0002

${ }^{4} \mathrm{I}$ am aware that intra-Christian differences over the theology of the Eucharist (e.g. transubstantiation, the role of the presider, etc.) mean that different Christian communities would appropriate such a communitarian soteriology of sacrifice in different ways. Nevertheless, I think that many Roman Catholics, Protestants, Anglicans, and Eastern Orthodox could affirm the central tents of the approach outlined in this essay.
${ }^{5}$ J. Denny Weaver, "Violence in Christian Theology," Cross Currents 51, no. 2 (Summer 2001): 150-76, at 153. Emphasis in original.

${ }^{6}$ Weaver, "Violence in Christian Theology," 163.

7 This makes Weaver's denunciation of Constantinian Christianity and American imperialism inconsistent, inasmuch as these political entities embody the ideology of agency elevated above any social limitations. If agency saves, then late-modern capitalism represents a soteriological apotheosis that merits our collective assent. See Weaver, "Violence in Christian Theology," 168-69.

${ }^{8}$ Kathryn McClymond, Beyond Sacred Violence: A Comparative Study of Sacrifice (Baltimore: Johns Hopkins University Press, 2008), 27. http://dx.doi.org/2027/mdp.39015074063499 Emphasis in original.

${ }^{9}$ Brian K. Smith, Reflections on Resemblance, Ritual, and Religion (New York: Oxford University Press, 1989), 46. http://dx.doi.org/2027/mdp.39015014590536 Emphasis in original. See also Smith, "Sacrifice and Being," Numen 32 (1985): 71-87. http://dx.doi.org/10.1163/156852785X00166

${ }^{10}$ The Śatapatha Brāhmana according to the Text of the Māhyandina School [2.2.2.1], vol. 1, trans. Julius Eggeling, Sacred Books of the East, vol. 12 (Oxford: Oxford University Press, 1882), 308.

${ }^{11}$ For primary source texts giving details of the aśvamedha, see Textual Sources for the Study of Hinduism, eds. and trans. Wendy Doniger O'Flaherty, Daniel Gold, David Haberman, and David Shulman, Textual Sources for the Study of Religion (Manchester: Manchester University Press, 1988; Chicago: University of Chicago Press, 1990), 14-17; Kātyāyana Śrauta Sūtra \{Rules for the Vedic Sacrifices\}, trans. H. G. 
Ranade (Poona: H. G. Ranade and R. H. Ranade, 1978), $532-50$.

http://dx.doi.org/2027/mdp.39015043534059; see also Asko Parpola, "The Coming of the Aryans to Iran and India and the Cultural and Ethnic Identity of the Dāsas," Studia Orientalia 64 (1988): 195-302, at 253.

${ }^{12}$ Śatapatha Brāhmaṇa [3.8.1.15], vol. 2, trans. Eggeling, Sacred Books of the East, vol. 26 (Oxford: Oxford University Press, 1885), 18990.

${ }^{13}$ Girard, "The Anthropology of the Cross: A Conversation with René Girard," epilogue in The Girard Reader, ed. James G. Williams (New York: Crossroad, 1996), 274.

${ }^{14}$ The Rig-Veda [RV 1.162.9, 11], trans. Wendy Doniger O'Flaherty, Penguin Classics (London: Penguin Books, 1981), 90.

${ }^{15}$ Mcclymond, 62.

${ }^{16}$ McClymond, 64.

${ }^{17}$ Brian K. Smith, "Sacrifice and Being," 72. Emphasis in original.

${ }^{18}$ Rig Veda [10.90.6, 12-13], trans. Raimundo Panikkar, in The Vedic Experience/Mantramañjari: An Anthology of the Vedas for Modern Man and Contemporary Celebration (Delhi: Motilal Banarsidass, 1977), 75-76.

${ }^{19}$ For an opposing view, one that disagrees with Smith's position on the constitutive character of vedic sacrifice, cf. J. C. Heesterman, "Hinduism and Vedic Ritual," review of Reflections on Resemblance, Ritual and Religion, by Brian K. Smith, History of Religions 30, no. 3 (Feb. 1991): 296-305. http://dx.doi.org/10.1086/463230 Here Heesterman claims that all religion cannot impose meaning on "living reality," but only proposes an otherworldly order beyond life and death.
${ }^{20}$ Bruce Lincoln, "The Indo-European Myth of Creation," History of Religions 15 (1975): 121-45, at 139. http://dx.doi.org/10.1086/462739

${ }^{21}$ Heim, 143.

${ }^{22}$ See Heim, 143.

${ }^{23}$ See Girard, Things Hidden, 180.

${ }^{24}$ Girard, Evolution and Conversion: Dialogues on the Origin of Culture (New York: Continuum, 2007), 217.

${ }^{25}$ McClymond, 147. Emphasis in original.

26 Mary Douglas, How Institutions Think (Syracuse: Syracuse University Press, 1986), 4. http://dx.doi.org/2027/mdp.39076000515929 ${ }^{27}$ See Luther, "The Pagan Servitude of the Church," trans. Bertram L. Woolf, in Martin Luther: Selections from His Writings, ed. John Dillenberger (New York: Doubleday, 1961), 286-88.

http://dx.doi.org/2027/uc1.32106006102807

${ }^{28}$ The Vedânta-Sûtras with the Commentary by Sańkarâkârya, vol. 1, trans. George Thibaut, Sacred Books of the East, vol. 34 (Oxford: Oxford University Press, 1890), 10.

${ }^{29}$ The opposition between Mīmāmssakas and early Vedāntins has been given a very nuanced treatment in Mìmāmsa and Vedānta: Interaction and Continuity, ed. Johannes Bronkhorst (Delhi: Motilal Banarsidass, 2007). http://dx.doi.org/2027/mdp.39015081839931

30 Brihad-äranyaka Upanișad [1.5.17]; in The Principal Upanișads, ed. and trans. Sarvepalli Radhakrishnan (Atlantic Highlands, NJ: Humanities Press International, 1992), 179.

${ }^{31}$ See Chāndogya Upanișad [3.16.1, 3, 5]; in The Principal Upanișads, 394-95.

${ }^{32}$ Colin E. Gunton, The Promise of Trinitarian Theology, $2^{\text {nd }}$ ed. (Edinburgh: T\&T Clark, 1997), 205.

http://dx.doi.org/2027/mdp.39015046503473 A 
66 Christopher Denny

prime exponent of the continuing validity of sacrifice in understanding Christian atonement is Robert J. Daly. Among his works on the subject, see Sacrifice Unveiled: The True Meaning of Christian Sacrifice (New York: T\&T Clark, 2009). 